\title{
HISTORY
}

\section{Auricular Flutter and Fibrillation}

\author{
W. A. Jolly and W. T. Ritchie \\ From the Laboratory of Physiology of the University of Edinburgh
}

\section{METHOD OF EXAMINATION}

\section{The Sensitiveness of the Instrument}

The following research upon the human electrocardiogram has been carried out by means of the Cambridge model of Einthoven's string galvanometer. The form of curve obtained from the heart varies as the conditions under which it is recorded are varied and depends upon the construction of the instrument employed, the strength of magnetic field, tension of moving conductor, etc.. For accurate interpretation and comparison with results obtained by other observers it is therefore essential that close attention be paid to the capacities of the particular instrument used and its adjustment. In the galvanometer employed the electromagnet is wound with thick wire of small resistance through which is passed a current of 9 Ampères derived from a battery of accumulators. The constant current supplied by the City of Edinburgh was at first made use of and answered well for the purpose of electrocardiogram registration. Such a current is, however, liable to slight fluctuations, which under certain conditions may interfere with results and for greater accuracy a battery of accumulators has been substituted. A stream of cold water is passed through coils of lead tubing surrounding the magnet in order to obviate the changes in tension of the string which would be caused by the heating effects of the magnet circuit. The image of the silvered quartz fibre is projected with a magnification of 820 diameters by the light of a Siemens and Shuckert are lamp of 20 Ampères upon a cylindrical lens. Behind the lens is the horizontal slit whose breadth may be increased or diminished in accordance with the speed given to the carrier of the photographic plate. The plate is drawn up vertically behind the slit by means of a piston working in an oil cylinder when slow and intermediate rates of movement are desired. For the rapid rate, which is necessary to measure the deflection time of the string in control curves, the carrier is shot across the slit by means of a spring. The projecting system consists of a Zeiss achromatic objective $A A$ used as condenser, apochromatic objective of $16 \mathrm{~mm}$. focus and compensating eyepiece No. 12 . An alum bath with parallel glass sides is placed before the projecting microscope to diminish the heating effect of the light.

The arrangement of the compensating circuit is similar to that used by Einthoven. The circuit from an accumulator charged to indicate 2 Volts is passed through a Siemens resistance box in which is placed $20,000 \mathrm{Ohms}$ and also through a dial rheostat from which a derived current enters the galvanometer circuit. Before introducing the electrodes and subject into the galvanometer circuit a large resistance is placed in series with the string. Any difference of potential is then compensated roughly and on diminishing and finally removing the series resistance exact compensation is obtained. The sensitiveness of the instrument is then adjusted by altering the tension of the string until a deflection of the desired number of millimeters is caused by a known difference of potential introduced by the dial rheostat.

The electrodes are of the form commonly employed for electrocardiograms and consist of glass jars containing a saturated solution of zinc sulphate, in which lie amalgamated zinc plates, and porous jars filled with salt solution in which the hands or feet of the subject are immersed. The apparatus is so arranged that the electrode taking the potential of the base of the heart or right ventricle is connected with the lower end of the string. A current downwards through the string gives rise to a deflection upwards on the photographic plate.

The resistance of the subject is measured by substituting for him a resistance box and introducing resistance until the deflection to a known difference of potential is the same as that obtained with the subject in the galvanometer circuit. In some 
cases Kohlrausch's telephone method has been employed.

The resistance of the string is 5,000 Ohms.

Some idea of the sensitiveness for weak currents of the particular instrument employed may be obtained from Fig. 10 which records the deflection given with a current of $2.2 \times 10^{-10}$ Ampères. The time-marker indicates seconds and the vertical lines which are produced by a rotating toothed disc and are not regularly timed, shew the direction of the slit. The deflection time is long, amounting to many seconds. $1 \mathrm{~mm}$. ordinate represents about $3.4 \times 10^{-11}$ Ampères, and fractions of a millimeter may be estimated. The irregularities on the curve which coincide with the vertical lines are due to alterations in the tension of the string brought about when it is in a relaxed condition by variations in temperature accompanying the periodical shadowing of the light as the teeth of the rotating disc pass in front of the projecting microscope. Such irregularities may be overcome by using a light filter of copper ammonium sulphate.

In recording by means of the string galvanometer, a curve such as the electrocardiogram, in which rapid alternations of current are present, it is important to consider the tension to be given to the string, for upon this the sensitiveness and time of deflection depend. As the string is relaxed the deflections become slower and if these are less rapid than the oscillations of the current to be measured the curve will not render the latter accurately, and to obtain a true picture a curve must be calculated as is done in the case of the capillary electrometer from the properties of the particular instrument employed and the details of the directly recorded curve. It is therefore necessary, if trustworthy data are to be collected, to impart to the string such a tension that the various summits of the electrocardiogram will appear undistorted, or if greater relaxation is used, to measure and record the deflection time of the instrument at the sensitiveness employed in order that the results may be compared with those obtained by other instruments.

The sensitiveness of the string galvanometer in Leyden-the original instrument-is so regulated for the study of the human electrocardiogram that, with a magnification of 660 diameters a difference of potential of 1 millivolt introduced into the circuit containing galvanometer and subject, or resistance box substituted for him, gives a deflection of $10 \mathrm{~mm}$.. The records so obtained have been compared with the calculated curve of the capillary electrometer ${ }^{7}$ and found to be closely similar. The summits $P, Q, R, S$ and $T$, are present in both curves and have the same relative height. The galvanometer curves recorded by the instrument so regulated present fairly accurately the variations of potential occurring at the electrodes, although some slight correction is necessary for the high and steep summit $R$, and students of the electrocardiogram very generally, where details of control curves are published, have used a sensitiveness such that 1 millivolt equals one centimeter. This does not, however, in itself permit of exact comparison between results obtained from different instruments, since, apart from variations in strength of magnetic field, etc., the electrical resistance of the subject varies.

Samojloff ${ }^{72}$ has published electrocardiograms photographed under varying conditions of tension of string and strength of magnetic field, accompanied by control curves taken with a rapid rate of plate carrier, so that the deflection time can be accurately determined in the several cases. It is shewn that the curve presents all the summits when the deflection time is 0.024 second. When the tension is diminished so that the control deflection becomes twice as great the deflection time becomes 0.06 second. The summits of the electrocardiogram are then in general higher, especially $T$, but the deformation of the curve is evident from the fact that summit $S$ is no longer visible.

\section{AURICULAR FIBRILLATION IN THE HUMAN HEART}

\section{Resumé of the Literature on the Action of the Auricles in Perpetual Arrhythmia of the Heart}

In the earlier part of this paper we have discussed fully a case where a series of regular auricular waves is presented in the electrocardiogram and by mechanical registration; and we have brought forward the evidence which leads us to conclude that the condition is one of flutter rather than fibrillation. We now proceed to discuss auricular fibrillation.

Perpetual arrhythmia-the "nodal rhythm" of Mackenzie-is a distinct form of cardiac arrhythmia. Mackenzie shewed that it is associated with a ventricular venous pulse and that the auricles no longer contract at their proper time in the cardiac cycle. It has been suggested that perpetual arrhythmia of the ventricles is associated with:- 
1. Paralysis, or asthenia, of the auricles Mackenzie, ${ }^{55}$ Gerhardt ${ }^{20}$ Lingbeek and Vrijdag ${ }^{50}{ }^{50}$ Hewlett,${ }^{33}$ Theopold ${ }^{77}$ Magnus Alsleben, ${ }^{63} \mathrm{Hay}^{25}$ Joachim,${ }^{40}$ Rautenberg, ${ }^{69}$ Hering, ${ }^{29}$ Samojloff and Steskinsky, ${ }^{73}$ and Strubell. ${ }^{76}$ Hoffmann $^{36}$ found that the auricular deflection $P$, was sometimes, but not constantly, absent.

2. Contraction of the Auricles simultaneously with the Ventricles, owing to $(a)$ increased excitability of the auriculo-ventricular node-the "nodal rhythm" of Mackenzie. ${ }^{57,59}$ The problem has also been investigated by Lohmann, ${ }^{51}$ Kraus and Nicolai, ${ }^{45}$ and Lewis, ${ }^{47}$; or $(b)$ a sino-auricular block comparable to the first Stannius ligature. This theory propounded by Wenckebach ${ }^{79}$ found support in the experimental researches of Engelmann, ${ }^{17}$ Lohmann, ${ }^{52}$ Hering, $^{31}$ and Cushny, ${ }^{3}$ in the clinical observations of Mackenzie, ${ }^{60}$ and in the pathological studies of Radasewsky, ${ }^{68}$ Dehio, ${ }^{5}$ Schönberg, ${ }^{75}$ Koch ${ }^{44}$ and Hedinger. ${ }^{27}$ Jäger, ${ }^{37}$ however, found that the rhythm of the heart remained unchanged after destruction of the sino-auricular node.

3. Auricular Fibrillation. Since Ludwig and Hoffa, ${ }^{54}$ recorded their classical observations it has been known that the application of a faradic current to the ventricles may induce fibrillar contraction of the ventricular musculature. Vulpian, ${ }^{78}$ MacWilliam, ${ }^{62}$ Jellinek, ${ }^{39}$ and Winterberg, ${ }^{81,82}$ shewed that when the ventricles are in fibrillar contraction the auricles usually beat in a co-ordinate manner. The researches of MacWilliam, ${ }^{62}$ Philips $^{66}{ }^{6}$ Fredericq ${ }^{19}$ and Winterberg, ${ }^{82}$ demonstrated that when the auricles are in fibrillation the ventricles do not usually pass into fibrillation but that their rhythm becomes wholly disorderly. The suggestion that perpetual arrhythmia of the human ventricles might be associated with auricular fibrillation was brought forward by Cushny and Edmunds, ${ }^{4}$ Evidence in favour of this theory may be found in the graphic records published by Mackenzie ${ }^{56,61}{ }^{5 c h m o l l}{ }^{74}{ }^{74}$ ewlett, ${ }^{34}$ Lewis, $^{48}$ and Hay, ${ }^{26}$ and in one of the electrocardiograms recorded by Kraus and Nicolai. ${ }^{45}$ The question of auricular fibrillation has also been discussed by Hering, ${ }^{30}$ Hewlett, $^{33}$ and Hirschfelder. ${ }^{35}$ The important researches of Rothberger and Winterberg, ${ }^{71}$ and of Lewis ${ }^{48}$ shewed the essential similarity of the electrocardiographic records in perpetual arrhythmia of the human heart and in experimental auricular fibrillation.

\section{Clinical Features, Graphic Records and Electrocardiograms of Cases of Perpetual Arrhythmia of the Ventricles}

In ten cases of perpetual arrhythmia we have studied the action of the auricles by means both of electrocardiograms and mechanical records.

CASE II, Greengrocer, aged twenty, under the care of Dr. G. A. Gibson, in the Royal Infirmary. The patient had suffered from whooping cough at the age of three, and from scarlet fever at the age of ten, but he had never suffered from acute rheumatism. For four months he had complained of "fluttering of the heart" which he had first experienced while walking down a hill towards his work. He had no pain or dropsy, and very little breathlessness. The apex-beat was in the fifth left intercostal space, in the mammillary line; a well marked systolic thrill accompanied by a loud blowing murmur were perceptible at the apex of the heart. The arterial pulse was continually irregular.

In Fig. 2 the jugulo-carotid tracing shews slow respiratory movements, and also elevations representing $c, v$, and $h$ waves. In addition there is a series of small and fairly rhythmic waves indicated by the letters $a$. These $a$ waves, which are most evident during the longer diastolic phases, occur at a rate of about 400 per minute. They are to be regarded as evidence of auricular contractions.

Fig. 21 gives the electrocardiogram from CASE II by derivation III. The summit $R$ is upwardly directed in the curves obtained by the three methods of derivation from this patient. $T$ consists of a downward deflection succeeded, most markedly when derivation III is employed, by an upward deflection. There are well marked waves on the curve occurring at a rate of about 504 per minute. These waves are not continuous but noticeably intermittent. In Fig. 21 at $a$ is seen a period in which they are absent.

\section{SUMMARY}

Small, rapid deflections, expressing the tone of the skeletal muscle may be present in the electrocardiogram.

These deflections can be differentiated from the slower deflections due to auricular flutter and fibrillation.

In CASE $I$ the rhythmic auricular flutter at the rate of 250 to 300 per minute was studied by mechanical methods of registration and by 


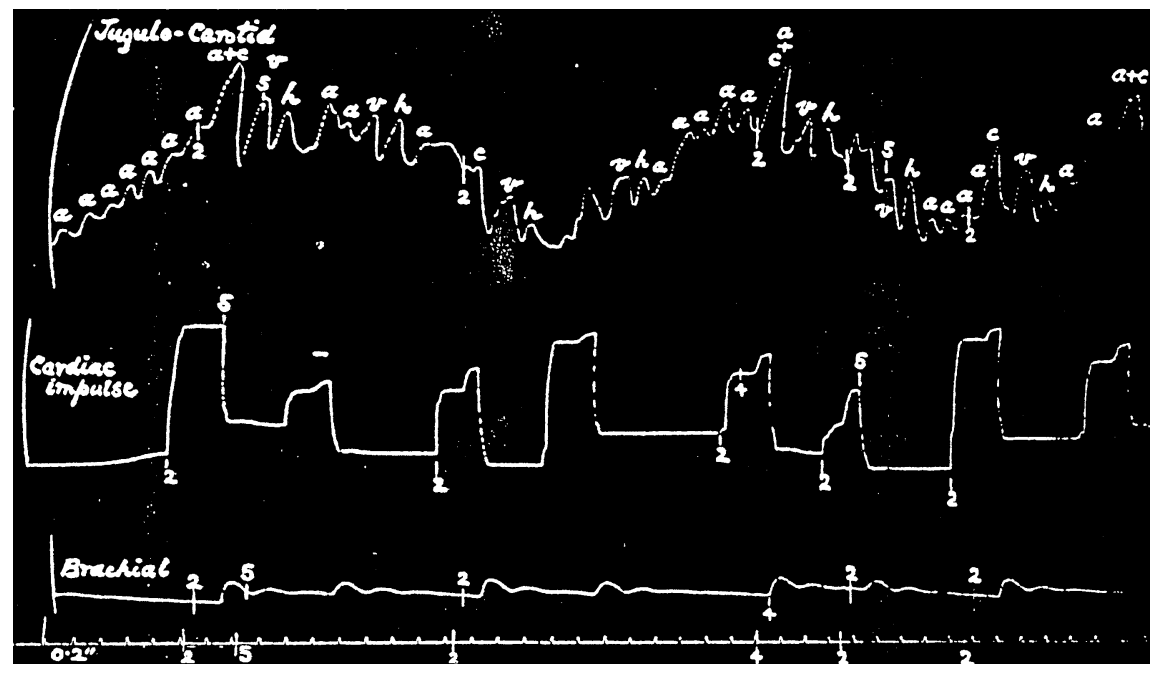

Figure 2. CASE /I. Perpetual arrhythmia of the ventricles. During ventricular diastole there is a series of positive waves, $a$, in the jugulo-carotid tracing.

electrocardiograms. By derivations II and III the curves were diphasic.

In ten cases of perpetual arrhythmia of the human ventricles, the action of the auricles was studied by means of electrocardiograms and mechanical registration. Jugulo-carotid tracings often reveal evidence of very rapid, irregular, feeble, auricular contractions. The electrocardiograms from all the cases presented irregular oscillations whose rates ranged in the several cases from 390 to 522 per minute.

In dogs whose auricles had been subjected to faradisation similar frequent and irregular oscillations at the rate of about 612 per minute were recorded in electrocardiograms.

Electrocardiograms from cases of perpetual arrhythmia of the human ventricles and from animals whose auricles have been submitted to faradisation agree with those in CASE I in presenting a series of frequent, small deflections in place of the usual summit $P$. They differ from them, however, in the irregularity of the waves and in their greater rate. Moreover, by no derivation do they shew a diphasic appearance. The two sets of waves are not identical. Those in CASE I are regarded as evidence of auricular flutter; those in perpetual arrhythmia of the human ventricles and in animals whose auricles had been subjected to faradisation may be attributed to fibrillation of the auricles.

\section{REFERENCES}

1. Buchanan. Quart. Journ. of Exper. Physiol., 1908, I, 211. 2. Cowan \& Ritchie. Quart. Journ. of Med., 1910, IV, 55.

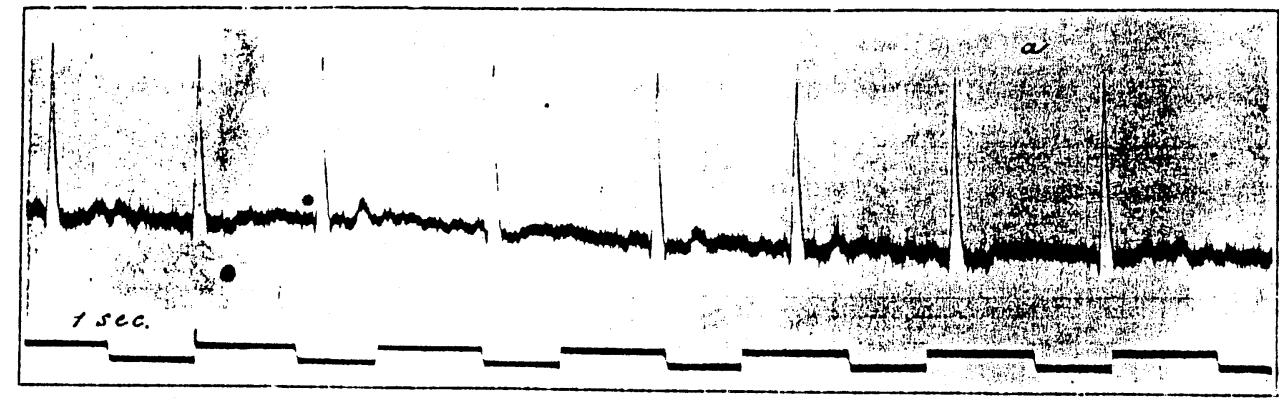

Figure 21. $\times \frac{5}{6.5}$ Electrocardiogram from CASE // by derivation III shewing irregular auricular waves occuring at a rate of about 504 per minute. The waves are intermittent. At $a$ is seen a period in which they are absent. 
3. Cushny. Heart, 1909, I, 1.

4. Cushny \& Edmunds, Studies in Pathology, Aberdeen, 1906; Amer. Journ. Med. Sci., 1907 CXXXIII, 66.

5. Dehio. Deutsch. Archiv f. klin. Med., 1899, LXII, 1

6. Dittler. Archiv f. d. ges. Physiol., 1909, CXXX, 400

7. Einthoven. Onderzoek. Physiol. Lab. Leiden, 1907, Tweede Reeks, VI, 106

8. Einthoven. Ibid., 1908, Tweede Reeks, VII, 1, Fig. 17.

9. Einthoven. Ibid., Fig. 22.

10. Einthoven. Ibid., Fig. 23.

11. Einthoven. Ibid., Fig. 30.

12. Einthoven. Archiv f. d. ges. Physiol., 1908, CXXII, 517.

13. Einthoven. Ibid., 1908, CXXII, 579, Fig. 36.

14. Einthoven. Ibid., 1908, CXXII, 550.

15. Einthoven. Ibid., 1908, CXXIV, 246.

16. Einthoven. "Lehrbuch d. vergleich. Phys. d. Haussäugetiere:" Ellenberger u. Scheunert, Berlin, 1910, 520.

17. Engelmann. Archiv f. Anat. u. Physiol.; 1903, phys. Abth., p. 505.

18. Eppinger \& Rothberger. Wien. klin. Wochenschr., 1909, XXII, 1091

19. Fredericq. Archives internat. de physiol., 1904-1905, II, 281.

20. Gerhardt. Archiv f. exper. Path. u. Pharmak., 1902, XLVII, 250.

21. Gibson. Edin. Med. Journ., 1905, N.S. XVIII, 9.

22. Gibson. Brit. Med. Journ., 1906, II, 1113.

23. Gotch. Heart, 1910, I, 235.

24. Hay. Edin. Med. Journ., 1907, XXI, 40.

25. Hay. "Graphic Methods in Heart Disease," London, 1909, 105.

26. Hay. Liverpool Med.-Chir. Journ., 1910, XXX, 220.

27. Hedinger. Frankf. Zeitschr. f. Pathol., 1910, V, 296.

28. Hering. Deutsch. Archiv f. klin. Med., 1908, XCIV, 185.

29. Hering. Ibid., 1908, XCIV, 205.

30. Hering. Münch. med. Wochenschr., 1909, LVI, 2483.

31. Hering. Archiv f. d. ges. Physiol., 1909, CXXVII, 155

32. Hertz \& Goodhart. Quart. Journ. of Med., 1909, II, 213.

33. Hewlett. Journ. of Med. Research, 1907-1908, XVII, 119.

34. Hewlett. Arch. of Intern. Med., 1908, II, 139.

35. Hirschfelder. Johns Hopkins Hosp. Bull., 1908, XIX, 322.

36. Hoffmann. Münch. med. Wochenschr., 1909, LVI, 2259.

37. Jäger. Deutsch. Archiv f. klin. Med., 1910, C, 1.

38. James. Amer. Journ. Med. Sci., 1908, CXXXVI, 469.

39. Jellinek. Archiv f. d. ges. Physiol., 1908, CXXIV, 271.

40. Joachim. Deutsch. med. Wochenschr., 1908, XXXIV, 2207.

41. Kahn. Archiv f. d. ges. Physiol., 1909, CXXVI, 197.

42. Kahn. Ibid., 1910, CXXXII, 209.

43. Keith. Journ. of Anat. and Physiol., 1908, XLII, 1.

44. Koch. Berlin. klin. Wochenschr., 1910, XLVII, 1108.

45. Kraus \& Nicolai. Ibid., 1907, XLIV, 765.
46. Kronecker \& Schmey. Sitzungsb. d. könig. preuss. Akad. d. Wissensch. zu Berlin, physik.-math. Classe, 1884, p. 87.

47. Lewis. Heart, 1909, I, 43.

48. Lewis. Ibid., 1910, I, 306.

49. Lewis \& Mack. Quart. Journ. of Med., 1910, III, 273.

50. Lingbeek \& Vrijdag. Nederl. Tijdschr. voor Geneesk., 1907, LI, Vol. II, 409.

51. Lohmann. Archiv f. Anat. u. Physiol.; 1904, phys. Abth., p. 431.

52. Lohmann. Archiv f. d. ges. Physiol., 1908, CXXIII, 628.

53. Lommel. Deutsch. Archiv f. klin. Med., 1905, LXXXII, 495.

54. Hoffa \& Ludwig. Zeitschr. f. rat. Med., 1849, IX, 107.

55. Mackenzie. "The Study of the Pulse," Edin. \& London, 1902, 209.

56. Mackenzie. Amer. Journ. Med. Sci., 1907, CXXXIV, 12.

57. Mackenzie. Quart. Journ. of Med., 1907-1908, I, 39.

58. Mackenzie. Ibid. 1907-1908, I, 39. Plate 6, Fig. 10.

59. Mackenzie. Ibid., 1907, I, 481

60. Mackenzie. Heart, 1909, I, 23.

61. Mackenzie. "Diseases of the Heart," London, (Second Edit.), 1910, Figs. 54, 56, 57, 66, 182 and 235.

62. MacWilliam. Journ. of Physiol., 1887, VIII, 296.

63. Magnus-Alsleben. Deutsch. Archiv f. klin. Med., 1909, XCVI, 346.

64. Nicolai. Nagel's Handb. d. Physiol. d. Menschen, Berlin, 1905, I. 661.

65. Nicolai. Zentralb. f. Physiol., 1908, XXI, 678.

66. Philips. Arch. internat. de physiol., 1904-1905, II, 271.

67. Piper. Archiv f. d. ges. Physiol., 1907, CXIX, 301.

68. Radasewsky. Zeitschr. f. klin. Med., 1895, XXVII, 381.

69. Rautenberg. Münch. med. Wochenschr., 1909, LVI, 378; Samml. klin. Vorträge, 1909, N.F., No. 557-558; inn. Med. $171-172$, s. $123 ; 137$.

70. Ritchie. Proc. Roy. Soc. of Edin., 1905, XXV, 1085.

71. Rothberger \& Winterberg. Wien. klin. Wochenschr., 1909, XXII, 839.

72. Samojloff. "Elektrokardiogramme," Jena, 1909.

73. Samojloff \& Steshinsky. Münch. med. Wochenschr., 1909, LVI, 1942.

74. Schmoll. Amer. Journ. Med. Sci., 1908, CXXXVI, 663.

75. Schönberg. Frankf. Zeitschr. f. Pathol., 1908, II, 153; 462.

76. Strubell. Verhandl. d. Kongr. f. in. Med., 1909, XXVI, 623.

77. Theopold. Deutsch. Archiv f. klin. Med., 1907, XC, 77.

78. Vulpian. Arch. de physiol. norm. et pathol., 1874, VI, 975.

79. Wenckebach. Archiv f. Anat. u. Physiol., 1907, phys. Abth, p. 1.

80. Wenckebach. Ibid., 1908, Suppl. Bd., 53.

81. Winterberg. Zeitschr. f. exper. Pathol. u. Therap., 1907, IV, 636; Archiv f. d. ges Physiol., 1907, CXVII, 223; Ibid., 1908, CXXII, 361.

82. Winterberg. Ibid., 1909, CXXVIII, 471. 